\title{
How Does Nutrition Feature in Climate-Smart Agricultural Policy in Southern Africa? A Systematic Policy Review
}

\author{
Shaun Beattie (D) and Susannah M. Sallu* (D) \\ School of Earth and Environment, University of Leeds, Leeds LS2 9JT, UK; shaun.beattie123@gmail.com \\ * Correspondence: s.sallu@leeds.ac.uk
}

\begin{abstract}
The ability to produce and supply more food that is both nutritious and environmentally sustainable is a momentous challenge facing Africa. Where climate change is expected to negatively impact the agricultural resource of many parts of Southern Africa specifically. Climate-Smart Agriculture (CSA) has emerged as an approach considered capable of transforming and realigning agricultural systems to support food and nutritional security, and development under a changing climate. For sustainable food and nutrition security to be achieved, an effective policy environment is required that supports the widespread adoption of CSA application. In light of this context, this study aims to better understand nutrition's current position within CSA-related policy at the national level by systematically reviewing all agriculture-related policy documents across Malawi, Tanzania, and Zambia, published between 2010 and 2019. The main findings show that efforts to address nutrition are being made within all countries and a sizeable number of policies, with crop-diversification and intensification presented as popular practices promoted as part of CSA. Nonetheless, the widespread adoption of these efforts remains weak and policies lack detail and instruction for the delivery of nutritional security. Cross-ministerial collaboration is recognised as essential for an improved policy environment, but few provide plans to strengthen such linkages or to include nutritional strategies. Clearer actions and policy outlines that promote nutrition as part of CSA are necessary if more effective action is to be achieved.
\end{abstract}

Does Nutrition Feature in

Climate-Smart Agricultural Policy in Southern Africa? A Systematic Policy Review. Sustainability 2021, 13, 2785. https://doi.org/10.3390/su13052785

Academic Editor: Abiodun Oluwole Fatunbi

Received: 27 January 2021

Accepted: 26 February 2021

Published: 4 March 2021

Publisher's Note: MDPI stays neutral with regard to jurisdictional claims in published maps and institutional affiliations.

Keywords: nutrition; climate-smart agriculture; Malawi; Tanzania; Zambia; climate change; policy

\section{Introduction}

The population of continental Africa is expected to reach 2.4 billion people by 2050, with poorer countries, including Malawi, Tanzania and Zambia expected to see five-fold increases in population [1]. In the coming decades the ability to produce more food that is both nutritious and environmentally sustainable, and capable of feeding a growing population is a momentous challenge facing Africa [2,3]. African nations will need to improve the nutritional status of 256 million people currently considered undernourished whilst satisfying increasing demands for agricultural production [4]. This challenge is compounded as malnutrition remains one of the least addressed socio-economic and health related issues in the region, adversely affecting the health and wellbeing of adults and children $[5,6]$.

Many African countries have the potential to be food self-sufficient, substantially reducing present and future food deficits, by closing yield gaps through high-input agricultural practices [7]. Although possible, many challenges relating to the achievement of food and nutrition security are now intensified by the effects of climate change [8]. Global climate models indicate particular vulnerability within the Southern African region with major agricultural crop yields, including maize, millet, and sorghum anticipated to fall by $10-20 \%$ by $2050[9,10]$. The four pillars of food security will likely further be negatively impacted, comprising food availability, accessibility, utilization and system stability [11]. This will exacerbate the burden of malnutrition and the income generation of rural populations, undermining current efforts that reduce hunger. In turn undernutrition will weaken 
climate resilience and the coping strategies of vulnerable populations [12]. For it is the regions high dependence on rain-fed agriculture [13], low-resilience [14], and the fragility of its economics [15] that have left the region ill-equipped to tackle the harsh realities that climate change imposes.

Ensuring responses to climate change are effective will require careful consideration of all factors that influence resilience that relate to food systems, livelihoods and agricultural production [16]. These factors include the institutional environment, the policy context and the environmental conditions of a given context. Weak sectoral coherence and poor implementation of policy have both acted as significant constraints to effective food security and mitigation efforts $[17,18]$. Immediate-term disaster management issues, including droughts and floods, have taken precedence over longer-term strategies for climate adaptation and nutrition [19]. Given the far-reaching changes required within the sector, more ambitious policy options need developing [20].

The impacts of climate change on agricultural production requires governments and farmers to implement new strategies that alleviate these pressures [21]. In response to such concerns, Climate-Smart Agriculture (CSA) has emerged as an approach considered capable of transforming and realigning agricultural systems to support food and nutritional security, and development under a changing climate [22]. CSA aims to address three core objectives: sustainably increase agricultural activity and incomes; develop agricultural resilience to climate change; reduce and/or remove greenhouse gases through mitigation efforts [23]. CSA differs from "business-as-usual" agricultural development approaches by emphasising the capacity to implement flexible, context-specific solutions, that identify synergies and trade-offs among food security, adaptation and mitigation, as a basis for advising and reorienting policy in response to climate change [20]. Food and nutrition security will exist when access to an appropriately nutritious diet is supported by a sanitary environment, adequate health services and care, allowing for a healthy and active lifestyle [24]. As such, CSA acknowledges the role of diets in motivating agricultural productivity and draws attention to the diverse interconnections that span food supply, production, and consumption [25].

For sustainable food and nutrition security to be achieved, an effective policy environment that creates alignment across policy domains, accomplished through effective cross-ministry communication that allows for overlaps, gaps and trade-offs between departments to be overcome, is required [20]. An environment that can increase coordination across agricultural, climate change, development and food system policies, and one that ultimately cultivates, organises and supports the wide-spread adoption of CSA application [26]. Yet, policy support to agriculture in the region has historically proven highly volatile and unpredictable with insufficient attention paid to the prevention and risk mitigation of climate variability to food production [27]. Whilst not unique to the region, it is the weak efforts of policy makers and the disconnection between climate policy and agricultural policy that has thus far prevented Southern Africa from mainstreaming important agricultural practices [28].

With active development and implementation of CSA-facing policy across Southern Africa in recent years [29-31], the extent to which, and how, food and nutrition security is included in CSA-related policies requires study. This can be achieved through a systematic policy review. Previous discussion has been given to nutrition and CSA at household and village level respectfully [32,33], with some acknowledgment of its wider incorporation deemed necessary [34,35]. Previous policy reviews regarding CSA [36,37], have not, however, held a nutritional focus. Additionally, little to no analysis of policy documentation has systematically assessed CSA related policy environments with a specific focus on nutrition. There is, therefore, considerable interest in understanding what constitutes an enabling policy environment for the incorporation of nutrition into CSA related policy.

In light of this context, this study aimed to better understand nutrition's current position within CSA-related policy at the national level by systematically reviewing all agriculture-related policy documents across Malawi, Tanzania, and Zambia. As policy 
documents showcase the cultivation of pre-existing social processes, they allow relevant stakeholder views to be reflected in their writings and can be considered reliable accounts of existing policy paradigms within the region [38]. This is important because exact objectives and goals of CSA interventions will depend on the context, and given the multi-objective nature of CSA there is potential for trade-offs to be created that affect nutritional security, if not adequately considered. It is therefore hoped that this research will provide valuable new evidence to potential policy-makers and relevant stakeholders who hold an invested interest in the interactions between policy, CSA, and nutrition.

\section{Materials and Methods}

\subsection{Rationale for Country Selection}

At the time of study (July 2019) Malawi, Tanzania and Zambia were chosen given their mutual status as a Least Developed Country (LDC) by the United Nations [39]—defined to be low-income countries facing severe impediments to sustainable development [40]. Each country displays high levels of vulnerability to economic and environmental shocks (measured by the economic vulnerability index) and significant human resource weakness (i.e., low levels of health, education and nutritional status specifically) [41]. As these criteria are further exacerbated by climate-related risks, CSA related policy is an important avenue for empowering governmental institutions considered weak or vulnerable [42].

Table 1 summarizes the development position of each country, with LDC status data provided by the UN [43-45]. All three countries identify agriculture as a catalyst for economic growth and development and are heavily dependent on rain-fed agriculture to facilitate this. Each country suffers from high levels of undernourishment and therefore strong policies that promote nutritional security should be considered essential. Given this set of relatable factors, this makes this set of countries an appropriate group for assessment used to reflect the wider Southern African region.

Table 1. Inclusion Criteria for Least Developed Country (LDC) Classification.

\begin{tabular}{|c|c|c|c|c|}
\hline & & \multicolumn{3}{|c|}{ Country } \\
\hline Inclusion Criteria $^{1}$ & Inclusion Threshold & Malawi & Tanzania & Zambia \\
\hline Gross National Income (GNI) per capita & $\$ 1025$ & $\$ 331$ & $\$ 902$ & $\$ 1561$ \\
\hline Human Assets Index & 60 or below & 52.5 & 56 & 58.6 \\
\hline * HAI Indicator: Percentage of Population Undernourished ${ }^{2}$ & 60 or below & 25.9 & 32.3 & 45.9 \\
\hline Economic Vulnerability Index (EVI) & 36 or above & 47.1 & 27.9 & 40.5 \\
\hline
\end{tabular}

${ }^{1}$ : Criteria and data provided by United Nations Least Developed Country Profiles [43-45]. ${ }^{2}$ : Sub-inclusion of nutrition. *: HAI indicator is provided given research objectives.

\subsection{Collection of Policy Documents}

An internet search (using general search engines and key words and phrases related to ["Climate-Smart" AND "Agri-food Systems" AND "Policy" AND "Location"]) was conducted in July 2019 for all publicly available national policies related to agriculture (defined broadly to include livestock, fisheries and crops), nutrition, health and climate change, published between 2010 and 2019. Given the FAO first launched the CSA concept in 2010, this timescale is deemed appropriate for review.

The Food and Agricultural Organization's (FAO) FAOLEX database was primarily used to source relevant policy documents. For countries where appropriate policy documentation could not be retrieved, national ministerial websites involved in agricultural or nutrition related interventions (i.e., ministries of health, welfare, or agriculture), and their respective government portals, were systematically browsed for publication retrieval. 


\subsection{Screening and Selection of Documents}

The following inclusion criteria were used to include the policies in the analysis: (i) the policy is a publicly available document published between 2010 and 2019, (ii) the policy is the most up-to-date publication, (iii) the policy is of national concern, (iv) policy is related directly or indirectly to agricultural sector, (v) the policy addresses at least one CSA pillar (productivity, adaptation or mitigation). We report our findings as a systematic policy review. No document was excluded based on its title (e.g., "Policy" versus "Strategy" versus "Plan"), but it must specify its national intention. No documents were excluded due to duplication.

The primary researcher independently screened documents for the inclusion criteria with full document screening additionally reviewed by an independent expert researcher to avoid subjectively when finalizing provisional list of included documents. Followed by a second-round screening for eligibility of full-text documents by the primary researcher with exclusions made for policy documents considered inappropriate, or the selected document failed to sustain significant relevance to study objectives (see inclusion criteria).

\subsection{Description of Policies}

The search strategy identified 113 non-duplicate and potentially relevant policy publications for review (108 retrieved from FAOLEX, five retried from secondary research strategy) (Figure 1). Of these 113 documents, one policy document was eliminated prior to the full-text screening as it was reported to be available but full document could not be obtained.

Of the 112 documents assessed for eligibility, 51 documents were eliminated given their publication was prior to 2010, 12 documents were determined not to be the most up-to-date policy statement available (examples include: the Sixth National Development Plan of Zambia being replaced by the Seventh National Development Plan in 2017), two documents were not of national scope (focusing on small-scale issues), four were not considered significantly relevant to agriculture nor its practices and 22 final documents were removed given they failed to address at least one CSA pillar.

The second round screening of the remaining 21 documents further led to the exclusion of four more documents, removed as they failed to provide adequate resources for an extensive review. A finalized list of 17 documents were selected for inclusion in the analysis ( $\mathrm{MW}=6, \mathrm{TZ}=6, \mathrm{ZM}=5$, Table 2). International Organisation for Standardisation (ISO) country codes are provided for clearer country separation, where MW is Malawi, TZ is Tanzania and ZM is Zambia, and policy reference codes are used when referring to specific documents throughout (Table 2).

Table 2. List of National Policy Documents.

\begin{tabular}{lcc}
\hline \multicolumn{1}{c}{ National Policy Document } & Reference Code & Time Frame \\
\hline Malawi & & \\
National Resilience Strategy [46] & NRS & $2018-2030$ \\
Malawi Growth and Development Strategy III [47] & MGDS III & $2017-2022$ \\
National Agriculture Policy [48] & NAP & $2016-2020$ \\
Malawi National Irrigation Policy [49] & NIP & $2016-$ NR \\
National Fisheries Policy [50] & MW-NFP & $2012-2017$ \\
Malawi Agriculture Sector Wide Approach [51] & ASWAp & $2011-2015$ \\
\hline Tanzania & & \\
Tanzania Livestock Master Plan [52] & LMP & $2018-2025$ \\
The Second National Five Year Development Plan [53] & FYDP II & $2016-2021$ \\
National Fisheries Policy [54] & TZ-NFP & $2016-$ NR \\
Agricultural Sector Development Strategy II [55] & ASDS II & $2015-2025$ \\
Agricultural Sector Development Programme II [56] & ASDP II & $2015-2030$ \\
Agriculture Climate Resilience Plan [57] & ACRP & $2014-2019$ \\
\hline
\end{tabular}


Table 2. Cont.

\begin{tabular}{lcc}
\hline \multicolumn{1}{c}{ National Policy Document } & Reference Code & Time Frame \\
\hline Zambia & & \\
Seventh National Development Plan [58] & 7NDP & $2017-2021$ \\
National Policy on Climate Change [59] NPCC & $2016-$ NR \\
Second National Agricultural Policy [60] & SNAP & $2016-$ NR \\
Zambia's Second National Biodiversity Strategy and Action Plan [61] & NBSAP II & $2015-2025$ \\
National Agriculture Investment Plan [62] & NAIP & $2014-2018$ \\
\hline
\end{tabular}

NR, not reported.

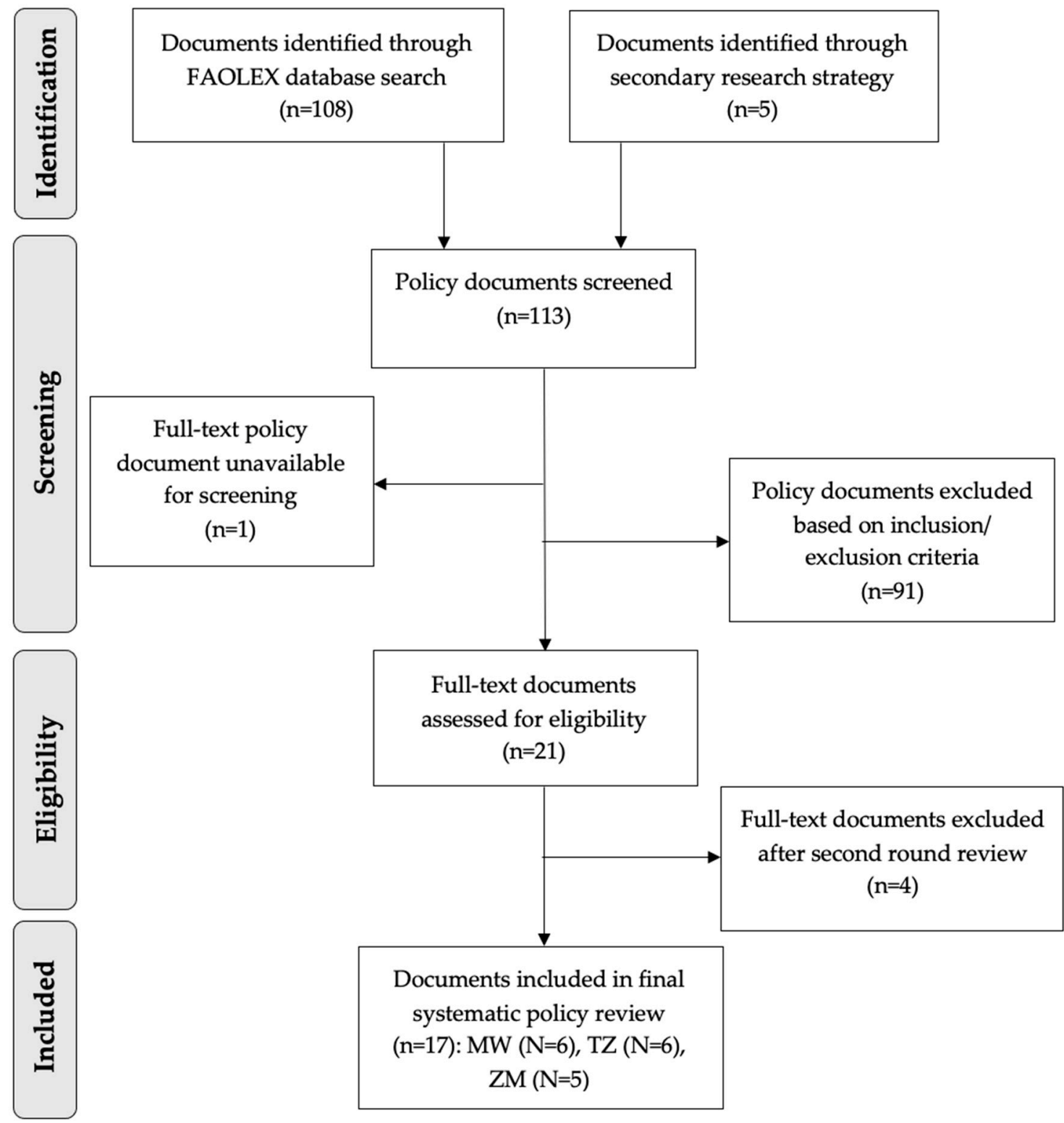

Figure 1. Policy Selection Process.

\subsection{Content Analysis}

Structured content analysis was conducted by coding the selected documents using Nvivo-12 software. Documents were coded independently by a singular reviewer and approved by an independent secondary reviewer to minimize bias induced by subjective coding. Each document selected for review was guided by the objectives and research 
questions presented in Table 3, with key words and sub-objectives for coding structured as a coding tree. Queries were constructed for each research question and respective sub-question in Nvivo to extract all relevant text electronically. Results are presented and grouped into country related categories.

Table 3. Coding Tree for Objectives and Sub-Objectives Used in Content Analysis.

Objective 1: How is Climate-Smart Agriculture (CSA) defined in these countries and their respective policy documents?

- How (if at all) is CSA defined and does this acknowledge nutrition?

- Which practices and tools that fit within CSA are prioritized?

Objective 2: To what extent is nutrition included in these policy documents?

- Is there acknowledgement of nutritional insecurity?

- What objectives and measures are in place to combat nutritional insecurity?

- Which of these measures are CSA related?

Objective 3: What actions are in place to improve the current policy environment?

- Is the importance of cross-ministerial cohesion recognized?

- What are the commonly cited challenges facing effective policy implementation?

- What efforts are currently in place to tackle this effectively? (Are these related to nutrition and CSA?).

\section{Results}

\subsection{CSA Definition and Characterization}

Of the 17 policy documents reviewed, 71\% (12/17) explicitly mention or cite CSA in their writings, but CSA related discussion varies significantly between countries and policies (Table 4). Zambian policy documents most commonly acknowledge CSA at least once (5/5), followed by Tanzania (3/6) and Malawi (3/6). Some only refer to CSA in passing; "there is a need for the government to promote climate-smart agriculture practices in the continued pursuit to promote food security at household and national levels" (p. 35) [61]. Others simply state intentions to promote CSA activity [47]. Whilst, others use the term extensively and provide large detail regarding what is understood to classify as CSA, as displayed within Tanzania's Agriculture Climate Resilience Plan 2014-2019 (TZ-ACRP) [57].

Only 2 documents attempt to define their understanding of CSA, both retrieved from Tanzania. The TZ-ACRP [57] is the only policy document to explicitly define its understanding of CSA, using the FAO's original definition (Table 4). Whilst the Agricultural Sector Development Programme Phase Two (TZ-ASDP II) [56], a more recent document that incorporates elements of the TZ-ACRP [57], instead uses its own interpretation of what constitutes CSA, seemingly setting out a national definition of CSA for Tanzania. CSA is further presented as an "integrative approach to address interlinked challenges of food security, climate change and mitigation through: (i) adapting and building resilience of agricultural and food and nutrition security systems to climate change at multiple levels; and (ii) reducing greenhouse gas emissions from agriculture (including crops, livestock and fisheries)" (p. 48). This definition differs from the FAO's as it incorporates food and nutrition security and mitigation efforts under one objective. No explicit definition of what defines CSA or its practices are found within either Malawian or Zambian publications, but both make efforts to promote the importance of developing and increasing CSA related activities.

All policies incorporate at least one CSA related practice into their objectives. Sustainable soil and water management practices are most commonly proposed (13/17 documents) with improved irrigation and water management systems subsequently deemed priority focus areas by several policies, considered critical adaptation measures (i.e., [51,56,62]). This is followed by cropland management activities (12/17); resilient crop varieties and diversification (10/17); soil fertility management (9/17); conservation agriculture (8/17); fishery management (8/17); livestock management (8/17); and agroforestry management 
(6/17). Cropland and soil fertility practices that include biofortification and integrated management systems, in particular, can deliver micronutrients to individuals and improve the nutritional status of soils but few documents promote these. No account for the institutional challenges in relation to the management of these systems, are however, presented.

Table 4. Policy Document CSA Definitions.

\begin{tabular}{|c|c|c|c|}
\hline Country & Is CSA Explicitly Defined? & CSA Definition & Policy Document \\
\hline Malawi & No & $\begin{array}{l}\text { No explicit definition but does seek to promote } \\
\text { "climate-smart" agriculture and sustainable land and water } \\
\text { management. }\end{array}$ & MGDS III \\
\hline \multirow[b]{2}{*}{ Tanzania } & \multirow[b]{2}{*}{ Yes } & $\begin{array}{l}\text { FAO definition of CSA_-"Agriculture that sustainably increases } \\
\text { productivity, resilience (adaptation), reduces/removes greenhouse } \\
\text { gases (mitigation) and enhances the achievement of national food } \\
\text { security and development goals (reduces poverty)" (p. 48). }\end{array}$ & ACRP \\
\hline & & $\begin{array}{l}\text { CSA is an interactive approach to address food security and } \\
\text { climate change through: } \\
\text { (1) Adapting and building resilience of agricultural and } \\
\text { food and nutrition security systems to climate change at } \\
\text { multiple levels. } \\
\text { (2) Reducing greenhouse gas emissions from agriculture } \\
\text { (inc. crops, livestock's and fisheries). }\end{array}$ & ASDP II \\
\hline \multirow{3}{*}{ Zambia } & \multirow{3}{*}{ No } & No explicit definition of CSA. & \\
\hline & & $\begin{array}{l}\text { Promotes adoption of CSA technologies for different } \\
\text { agro-ecological zones. }\end{array}$ & NPCC \\
\hline & & $\begin{array}{l}\text { Integrating climate-smart technologies necessary to buffer } \\
\text { against natural shocks (i.e., droughts, weakening seed and } \\
\text { animal varieties). }\end{array}$ & 7NDP \\
\hline
\end{tabular}

\subsection{Extent of Nutritional Inclusion in Policy}

Actions to address nutritional security are provided in 59\% (10/17) of reviewed documents ( $M W=5, Z M=3, T Z=2$ ). Of those papers that present ambitions to promote nutritional security, all but one document presents plans, efforts or measures to facilitate these efforts. The ZM-NAIP [62] identified the importance of food and nutrition security but failed to propose any measures to promote this. Five further policy documents incorporate 6 or more measures and are therefore considered more nutritionally inclusive $[47,48,57,58,60]$. No two policies possess an identical set of nutrition measures. Notable measures include the cultivation and consumption of indigenous crops and educating the population to consume them.

The diversification and intensification of crop production (7/17) and increased nutritional education of households (6/17) are the most commonly identified measures to promote nutritional security, appearing in $41 \%$ and $33 \%$ of documents respectfully. It is expected that by diversifying the food system a more diverse and nutritious range of produce can be obtained at the rural household level, allowing for improved awareness of those staple foods considered highly nutritious.

At least one CSA related measure is identified within all policy documents promoting nutritional security, except one [62]. The most common measures include crop diversification $(7 / 11)[47-49,51,55,56,60]$, and the promotion of bio-fortification of staple food crops $(4 / 11)[47,48,56,60]$. All identified measures that related to CSA are further displayed in Table 5. 
Table 5. Summary of Nutritional Security Related Objectives and Measures.

\begin{tabular}{|c|c|c|c|}
\hline Country & Policy Document & Nutritional Inclusion? & CSA Related Objectives and Measures \\
\hline \multirow{6}{*}{ Malawi } & NRS & YES & No recognition of nutrition \\
\hline & MGDS III & YES & $\begin{array}{l}\text { Measures: } \\
\text { (1) Promote technologies that reduce post-harvest } \\
\text { loses } \\
\text { (2) Promote bio-fortification } \\
\text { (3) Promote diversified crop and livestock production } \\
\text { (4) Promote research into the use of propagation and } \\
\text { conservation technologies of indigenous foods }\end{array}$ \\
\hline & NAP & YES & $\begin{array}{l}\text { Measures: } \\
\text { (1) Promote production and utilization of diverse } \\
\text { nutritious foods } \\
\text { (2) Promote bio-fortification of staple foods } \\
\text { (3) Promote universal food and nutrition education }\end{array}$ \\
\hline & NIP & YES & $\begin{array}{l}\text { Measures: } \\
\text { (1) Enhance crop diversification and intensification }\end{array}$ \\
\hline & MW-NFP & $\mathrm{NO}^{1}$ & No recognition of nutrition \\
\hline & ASWAp & YES & $\begin{array}{l}\text { Measures: } \\
\text { (1) Promote diversification of food production }\end{array}$ \\
\hline \multirow{6}{*}{ Tanzania } & LMP & $\mathrm{NO}$ & No recognition of nutrition \\
\hline & FYDP II & $\mathrm{NO}$ & No recognition of nutrition \\
\hline & TZ-NFP & $\mathrm{NO}^{2}$ & No recognition of nutrition \\
\hline & ASDS II & YES & $\begin{array}{l}\text { Measures: } \\
\text { (1) Improve food quality, diversity and reduce } \\
\text { prevalence of malnutrition } \\
\text { (2) Diversification of farming systems for improved } \\
\text { diets }\end{array}$ \\
\hline & ASDP II & YES & $\begin{array}{l}\text { Measures: } \\
\text { (1) Promote farm system diversification towards } \\
\text { improved risk management and food and nutrition } \\
\text { security } \\
\text { (2) Promote food fortification and blending techniques } \\
\text { (including bio-fortification) }\end{array}$ \\
\hline & ACRP & NO & No recognition of nutrition \\
\hline \multirow{5}{*}{ Zambia } & $7 \mathrm{NDP}$ & YES & No CSA related measures \\
\hline & NPCC & NO & No recognition of nutrition \\
\hline & SNAP & YES & $\begin{array}{l}\text { Measures: } \\
\text { (1) Promote diversification of agricultural production } \\
\text { and utilization } \\
\text { (2) Promote access to bio-fortified seed or vines for the } \\
\text { production of nutrient enhanced varieties } \\
\text { (3) Promote on-farm agro-processing }\end{array}$ \\
\hline & NBSAP II & $\mathrm{NO}$ & No recognition of nutrition \\
\hline & NAIP & $\mathrm{YES}^{3}$ & No CSA related measures \\
\hline
\end{tabular}

${ }^{1}$ : Policy notes importance of improving protein and micronutrient intake for Malawians but no strategies presented to improve food or nutrition security. ${ }^{2}$ : States objective "to develop a robust, competitive and efficient fisheries sector that contributes to food security and nutrition, growth of the national economy and improvement of the wellbeing of fisheries stakeholders while conserving environment" (p. 11) but no measures to promote this provided. ${ }^{3}$ : No plans or measures to fulfil nutritional security provided.

Little to no acknowledgement is explicitly given to CSA when presenting measures for nutritional security, but acknowledgment of the climatic related risk are found in 2/11 documents when discussing their objectives [46,62]. 


\subsection{Cross-Ministry Cohesion (Policy Environment)}

Acknowledgement of cross-policy/sectoral collaboration as an imperative for an improved policy environment is provided in $71 \%(12 / 17)$ of the reviewed documents, but at various degrees of detail. The MW-NFP [50] "promotes co-ordination and collaboration with other sectors in dealing with multi-sectoral issues, which have an impact on the environment and fishery resources" (p. 14), but does not provide any plans or measures to overcome this. Others, including the ZM-7NDP [58] not only identifies its importance but sets out strategies to enhance policy formulation.

Equal acknowledgement is provided across countries that for implementation to be achieved, coherence of related policies must be ensured through the encouragement of a multisectoral approach $[47,53,56,58,62]$. Ambitions to strengthen the linkages between agricultural and non-agricultural sectors is further identified in $8 / 17$ documents $[47,48,50,51,55,56,58,62]$, in the hope to align policy agendas and help all policies pursue similar national outcomes.

Challenges to effective policy implementation vary across documents but no significant difference between countries is found. Notable obstacles include: shortages of labour [46,47,51,60,62], lack of stakeholder representation [49-51,53], conflict of stakeholder interests $[53,56,61]$ and weak stakeholder collaboration $[53,61]$. No attempts to highlight obstacles were provided by 4 documents [48,52,54,59].

Actions to address the collaboration and participation of stakeholders are most commonly proposed to ensure an enabling policy environment (12/17 documents; Table 6). Strategies to strengthen knowledge sharing between ministries and stakeholders $(8 / 17 \mathrm{doc}-$ uments) $[47-49,51,55,58,59,61]$ are further observed to support stakeholder participation and to address capacity gaps. At the ministerial level, actions to strengthen inter-sectoral coordination and collaboration to streamline policies that promote coherence are noted in $7 / 17$ documents $[46,47,55,56,58,60,62]$. However, no further presentation of plans, measures or actions to successfully implement or facilitate this are found.

Table 6. Actions to Improve Policy Environment.

\begin{tabular}{|c|c|c|}
\hline Country & Policy Document & Actions To Improve Policy Environment \\
\hline \multirow{6}{*}{ Malawi } & NRS & $\begin{array}{l}\text { - } \quad \text { Prioritise collaborative learning to NRS } \\
\text { - }\end{array}$ \\
\hline & MGDS III & $\begin{array}{ll}\text { - } & \text { Promote stakeholder collaboration } \\
\text { - } & \text { Strengthen inter-sectoral coordination } \\
\text { - } & \text { Enhance policy coherence (multi-sectoral approach) } \\
\text { - } & \text { Promote environmental education and information sharing amongst stakeholders }\end{array}$ \\
\hline & NAP & $\begin{array}{ll}\text { - } & \text { Strengthen cross-ministerial linkages to ensure sustained development } \\
\text { - } & \text { Promote stakeholder participation in policy implementation } \\
\text { - } & \text { Improve farmer knowledge access }\end{array}$ \\
\hline & NIP & $\begin{array}{ll}\text { - } & \text { Enhance stakeholder participation in irrigation management } \\
\text { - } & \text { Encourage private sector investment } \\
\text { - } & \text { Develop training programs to address capacity gaps }\end{array}$ \\
\hline & MW-NFP & $\begin{array}{l}\text { - } \quad \text { Promote coordination and collaboration between related sectors } \\
\text { - } \quad \text { Promote participation of local fishing communities }\end{array}$ \\
\hline & ASWAp & $\begin{array}{ll}\text { - } & \text { Promote knowledge sharing and communication amongst ministries } \\
\text { - } & \text { Harmonize related policies } \\
\text { - } & \text { Promote smallholder participation in decision making } \\
\text { - } & \text { Improve donor coordination }\end{array}$ \\
\hline
\end{tabular}


Table 6. Cont.

\begin{tabular}{|c|c|c|}
\hline Country & Policy Document & Actions To Improve Policy Environment \\
\hline \multirow{6}{*}{ Tanzania } & LMP & No improvement actions presented \\
\hline & FYDP II & $\begin{array}{l}\text { - Create enabling environment for all stakeholders to participate in desired } \\
\text { economic and human development } \\
\text { - } \quad \text { Enhance coherence of policies and implementation }\end{array}$ \\
\hline & TZ-NFP & - $\quad$ Strengthen capacity for participation in regional and international obligations \\
\hline & ASDS II & $\begin{array}{l}\text { - Enhance inter-ministerial collaboration to share knowledge and create mitigation } \\
\text { and adaption measures }\end{array}$ \\
\hline & ASDP II & $\begin{array}{l}\text { - } \quad \text { Develop mechanisms for collaboration across all ASDP II stakeholders } \\
\text { - } \quad \text { Streamline policies across sectors to promote policy coherence }\end{array}$ \\
\hline & ACRP & No improvement actions presented \\
\hline \multirow{5}{*}{ Zambia } & $7 \mathrm{NDP}$ & $\begin{array}{ll}\text { - } & \text { Create platforms to promote all stakeholder participation } \\
\text { - } & \text { Strengthen synergies between various related institutions } \\
\text { - } & \text { Promote inter-sectoral linkages and synergies with national level indicators } \\
\text { - } & \text { Promote multi-sectoral development approach to sustainable development }\end{array}$ \\
\hline & NPCC & 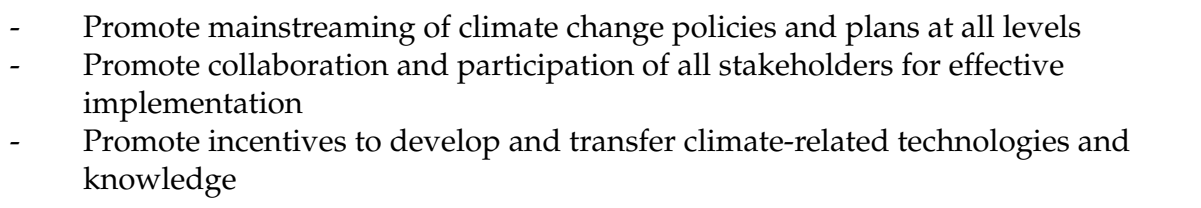 \\
\hline & SNAP & $\begin{array}{ll}\text { - } & \text { Promote stakeholder participation of knowledge and technology transfers } \\
\text { - } & \text { Strengthen stakeholder coordination } \\
\text { - } & \text { Harmonize public and private extension systems }\end{array}$ \\
\hline & NBSAP II & $\begin{array}{l}\text { - Promote effective knowledge sharing on conservation } \\
\text { - } \quad \text { Create enabling environments for establishment of community fishery areas } \\
\text { - } \quad \text { Encourage all stakeholder participation }\end{array}$ \\
\hline & NAIP & $\begin{array}{l}\text { - Promote stakeholder participation and coordination to enhance effective NAIP } \\
\text { implementation } \\
\text { - } \quad \text { Promote synergies with other government ministries }\end{array}$ \\
\hline
\end{tabular}

Efforts to improve policy environments that relate to CSA and nutrition are identified in 8 documents [47,48,53,55-58,62]. Enhanced CSA financing [48,56], improved seed fertilizer crop accessibility [55], and financial incentives for farmers [57] are notable avenues to enhance sustainable food and nutritional security, but are only identified once.

\section{Discussion}

\subsection{CSA Definition and Practices in National Policy}

CSA definitions and CSA related engagement varies significantly across countries and policies, with few defining or providing great detail on what constitutes CSA. In this study Tanzania is shown to have taken the most progressive strides in articulating what it understands to be CSA, both explicitly using the FAO's original definition [57] and creating its own interpretation, incorporating food and nutrition security and mitigation efforts under one objective [56]. At the time of study, Zambia and Malawi did not have specific climate-smart policies in place, but both countries made efforts to promote and develop increased CSA related activity. Malawi promotes 'climate-smart' in the broadest sense [47], but fails to prioritize CSA related targets into its planning, process or funding applications. Whereas, Zambia identifies CSA as an important priority in relation to both adaptation and mitigation actions [58,59], and further recognizes the role of "CSA practices in the continued 
pursuit to promote food security at household and national levels" (p. 35) [61], but this does not explicitly incorporate nutrition. This is, nonetheless, an important approach given some farmers have responded more positively to ambitions framed around climate change, than those simply labelled 'climate-smart' [63].

Given the historical ambiguity of CSA's foundational principles [64], perhaps such variation represents each countries reticence to definitively conclude what should constitute CSA in their given context. In Zambia in particular, nutrition is emphasized as a component of the productivity pillar of CSA in its Climate-Smart Agriculture Investment Plan [65] but this does not feature in its national policies examined here. No single guiding policy is further provided by any country at the time of writing, and the lack of clear understanding about the concept and how it should be implemented supports previous CSA assessment [66]. As such, there is potential for more explicit and ambitious policy statements that include nutrition as a component of food security in CSA to be created, across all countries.

A high number of CSA related practices are identified and this is expected given the diverse set of agricultural practices incorporated within CSA. All policies incorporate at least one CSA related practice into their objectives with sustainable soil and water management practices most commonly proposed. Improved irrigation and water management systems are subsequently deemed priority focus areas by several policies, considered critical adaptation measures $[51,56,62]$. This is justified given improved farm irrigation is twice as productive on average than pre-existing rain-fed systems in regards to food production [67]. Improvements to irrigation and water storage strategies can enhance efficiency, maintain crop yields and strengthen drought tolerance ultimately supporting the productivity and adaptation pillars of CSA. Nonetheless, common soil and water management challenges, including operation and maintenance responsibilities and costs to farmers, go unexplored with no focus towards nutrition.

Cropland and soil fertility practices including crop biofortification and integrated nutrient management systems are also notably presented. In addition to greater crop-yields, these can deliver more micronutrients to individuals and improve the nutritional status of soils overtime [68]. The widespread implementation of such practices across these countries does, however, remain weak. Often simply classified as policy-based adaptation actions intended for future application [69], that at the time of analysis lack strong application.

\subsection{Extent of Nutrition in National Policy}

Given nutrition is inextricably linked to agricultural development through food production, the fact only 11/17 reviewed documents attempt to address nutrition as an issue is concerning. When highlighted, crop-diversification and intensification are the most frequently promoted CSA measures, with crop-diversification commonly proposed through increased productivity of highly nutritive value crops (e.g., cassava, legumes, sweet potatoes), livestock and fish stocks (See $[47,48,60])$. The introduction of these economically attractive and drought-resilient crops can increase food availability and ensure food and nutritional security by establishing resilient agricultural systems [70,71]. Malawi specifically, has seen improvements to nutritional and dietary diversity in the past as a result of farm production diversity [72], strengthening the rationale for continued promotion in policy.

Measures to increase the nutritional education of households, children and small-scale farmers are also provided by more than half of the reviewed documents (e.g., [47,56,62]). Education is an important tool for informing households on the nutritional benefits of new crop seeds. The Tanzanian ACRP [57] specially recognises clear cases where education has significantly scaled up the adoption of CSA practices and has improved household knowledge on the nutritional risks relating to climate change. Education that promotes nutritious foods should continue to be used to improve the nutritional status of vulnerable populations. 
Few policies analysed, however, went beyond simply stating a desire to promote nutritional security activities and lack instruction for goal delivery. General statements are often used to describe actions and strategies for education and diversification. These include "mainstream food and nutrition awareness across all agricultural sectors" [56] and "promote the diversification of agricultural production" [60], neither statement significantly informative. Policies should seek to outline clearer actions to mobilise stakeholders in order for more effective action to be taken. Furthermore, the impacts of climate change on these practices also requires consideration by policy makers. Improving knowledge of the nutritional risks related to climate change is therefore important [57]. As such, given nutritional security comprises many complex factors unsolvable by a single intervention, policies should seek to improve education and access to nutritious food simultaneously, otherwise the impact of one alone is limited.

The absence of nutrition in a sizable number of these policies does not, however, necessarily reflect the actions being taken within each respective country. Interventions promoting nutritional security and CSA have previously been implemented in countries without a definitive policy being published [73], and this therefore should not be overlooked.

\subsection{Current Policy Environment}

Whilst acknowledgment of cross-policy/sectoral collaboration as an imperative for an improved policy environment is strong, plans to strengthen cross-ministerial linkages between agricultural and non-agricultural sectors are, however, less common (i.e., [48,60]) The recognition of broader development objectives, not specific to nutrition, provides some proof of ambition to improve the connections between climate and agriculture related policy. Nonetheless, this number of policies remains small. Analysis by England et al. [17] supports these findings, presenting overall sectoral coherence for Malawi, Tanzania and Zambia produced mediocre scores for policy coherence ranging from $46-61 \%$, where $100 \%$ equates to optimum cross-ministry coherence. These countries have further been shown to be lagging behind their regional neighbours, including Botswana and Swaziland [74].

In this study, actions to address weak collaboration and participation of stakeholders are most commonly proposed to ensure an enabling policy environment, promoting policy coherence (12/19 documents). Some acknowledge that stakeholders can enhance national and basin-level knowledge through shared information [47,51,60,61], indicating a desire to improve existing stakeholder participation. However, no actions to ensure sustained engagement are provided. Government ministries should seek to define clearer roles, responsibilities and targets as a result of collaborative efforts to better manage multistakeholder participation.

Challenges to effective policy implementation articulated in the documents vary but shortages of available trained labour are a notable concern [46,47,51,58,60,62]. Low labour availability has proven to be a constraint on the adoption of CSA related tools and practices by farmers [75]. Policies acknowledge that effective policy implementation and adoption is dependent upon the availability of resources (capital, labour and knowledge) by households. Policy actions to improve this are generally created through actions to increase household incomes $[48,56,57]$. Nonetheless, the policies analysed fail to realise that simply increasing incomes does not automatically improve education, food availability or nutrition security [75]. Policies should therefore seek more appropriate methods to increase the labour supply that also positively impacts nutritional security.

\section{Conclusions}

Climate-Smart Agriculture has emerged as an approach capable of transforming and realigning agricultural systems to support food and nutritional security under a changing climate, with Southern African governments exhibiting numerous policies and initiatives to promote CSA-related practices. In order for sustainable food and nutrition security to be achieved, an effective policy environment is imperative. Having received little research 
attention to date, this paper set out to understand what constitutes an enabling policy environment for the implementation of nutrition into CSA related policy. Focus was given to nutrition's current position within CSA related policy at the national level in three Southern African Countries-Malawi, Tanzania and Zambia.

This review concludes that at the time of writing, attempts to address nutrition are being made within all countries. Whilst all countries make efforts to promote the importance of CSA, few provide great detail in defining what should constitute CSA in their given context nor explicitly incorporate nutrition into these statements. Efforts to address nutritional security were found, but these lack detail and instruction for goal delivery. More explicit and ambitious policy statements that include nutrition as a component of food security in CSA are therefore required, across all countries. Increased consideration of nutrition interventions, scaled-up implementation of policies and a greater number of national commitments could ensure this [76].

Where attempts to address nutrition are identified in CSA policy, crop-diversification and intensification are presented as popular practices promoted as part of CSA. These can increase food availability and ensure food and nutritional security by establishing resilient agricultural systems [70,71]. The impacts of climate change on these practices, however, requires consideration by policy makers. Nutritional security is rarely exclusively concerned with the provision of adequate food supplies and improving stakeholder knowledge concerning the nutritional risks related to climate change and agricultural development are equally important [77].

Cross-ministerial collaboration is recognized as essential for an improved policy environment but few policies present plans to strengthen such linkages or include nutritional strategies. Reviewed policies identify challenges to successful coherence; however, explanations about why challenges to successful coherence are present and proposals to collaborate and harmonize policy efforts to improve coherence across agricultural and non-agricultural sectors are seldom. More research efforts to understand what successful policy coherence looks like in the context of agricultural development, food and nutrition security and climate change is, therefore, required to inform future policy.

Author Contributions: Authors co-designed the study and associate methodology. S.B. undertook the analysis and produced early drafts of the manuscript. S.M.S. supervised the analysis and provided support with the structuring and context of early drafts. S.M.S. also reviewed and provided editorial support to the final manuscript. All authors have read and agreed to the published version of the manuscript.

Funding: This work aligns with, and the staff time of S.M.S. was supported by, the Biotechnology and Biological Sciences Research Council through UK Research and Innovation Funded Global Challenges Research Fund-AFRICAP programme-grant number BB/PO27784/1.

Acknowledgments: This research was presented in the Biennial Climate Smart Conference held between 1-2 December 2020. The Forum for Agricultural Research in Africa (FARA) supported the publication charges with funding from the CAADP-XP4 funding from the EC.

Conflicts of Interest: The authors declare that they have no conflict of interest.

Disclaimer: The analysis and perspectives presented are those of the authors only and are independent of the institutions and organizations associated with the GCRF-AFRICAP programme.

\section{References}

1. UN (United Nations). World Population Prospects: The 2015 Revision, Key Findings and Advance Tables; The Department of Economic and Social Affairs of the United Nations: New York, NY, USA, 2015.

2. Garrity, D.P.; Akinnifesi, F.K.; Ajayi, O.C.; Weldesemayat, S.G.; Mowo, J.G.; Kalinganire, A.; Larwanou, M.; Bayala, J. Evergreen Agriculture: A robust approach to sustainable food security in Africa. Food Secur. 2010, 2, 197-214. [CrossRef]

3. Hall, C.; Dawson, T.P.; Macdiarmid, J.I.; Matthews, R.B.; Smith, P. The impact of population growth and climate change on food security in Africa: Looking ahead to 2050. Int. J. Agric. Sustain. 2017, 15, 124-135. [CrossRef]

4. FAO (Food and Agricultural Organisation of the United Nations). Africa Regional Overview of Food Security and Nutrition; FAO: Rome, Italy, 2019. 
5. Horton, S.; Shekar, M.; Ajay, M. Scaling up Nutrition: What Will It Cost? The World Bank: Washington, DC, USA, 2010.

6. FRAC (Food Research and Action Centre). Hunger and Wealth-The Impact of Poverty, Food Insecurity, and Poor Nutrition on Health and Well-Being; FRAC: Washington, DC, USA, 2017.

7. Pradhan, P.; Fischer, G.; van Velthuizen, H.; Reusser, D.; Kropp, J. Closing Yield Gaps: How Sustainable Can We Be? PLoS ONE 2015, 10, e0129487. [CrossRef]

8. Branca, G.; Tennigkeit, T.; Mann, W.; Lipper, L. Identifying Opportunities for Climate Smart Agriculture Investment in Africa; Food and Agriculture Organization of the United Nations (FAO): Rome, Italy, 2012.

9. IPCC (Intergovernmental Panel on Climate Change). Impacts, Adaptation, and Vulnerability. Part A: Global and Sectoral Aspects. Contribution of Working Group 2 to the Fifth Assessment Report of the Intergovernmental Panel on Climate Change; Cambridge University Press: Cambridge, UK, 2014.

10. Ramirez-Villegas, J.; Thornton, P.K. Climate Change Impacts on African Crop Production; CGIAR Research Program on Climate Change, Agriculture and Food Security (CCAFS): Copenhagen, Denmark, 2015; p. 27.

11. Gross, R.; Schoeneberger, H.; Pfeifer, H.; Preuss, H.-J. The four dimensions of food and nutrition security: Definitions and concepts. SCN News 2000, 20, 20-25.

12. Tirado, M.C.; Crahay, P.; Mahy, L.; Zanev, C.; Neira, M.; Msangi, S.; Brown, R.; Scaramella, C.; Coitinho, D.C.; Müller, A. Climate change and nutrition: Creating a climate for nutrition security. Food Nutr. Bull. 2013, 34, 533-547. [CrossRef] [PubMed]

13. Sdibé, Y.; Foudi, S.; Pascual, U.; Termansen, M. Adaptation to Climate Change in Rainfed Agriculture in the Global South: Soil Biodiversity as Natural Insurance. Ecol. Econ. 2018, 146, 588-596. [CrossRef]

14. Lipper, L.; McCarthy, N.; Zilberman, D.; Asfaw, S.; Branca, G. Climate Smart Agriculture: Building Resilience to Climate Change; Natural Resource Management and Policy, 52; Springer Nature: Basel, Switzerland, 2018; p. 630.

15. Nagarajan, C.; Pohl, B.; Rüttinger, L.; Sylvestre, F.; Vivekananda, J.; Wall, M.; Wolfmaier, S. Climate-Fragility Profile: Lake Chad Basin; Adelphi: Berlin, Germany, 2018; Volume 32.

16. Bryan, E.; Theis, S.; Choufani, J.; De Pinto, A.; Meinzen-Dick, R.S.; Ringler, C. Gender-Sensitive, Climate-Smart Agriculture for Improved Nutrition in Africa South of the Sahara. In A Thriving Agricultural Sector in a Changing Climate: Meeting Malabo Declaration Goals through Climate-Smart Agriculture, 9th ed.; International Food Policy Research Institute: Washington, DC, USA, 2017; pp. 114-135.

17. England, M.I.; Dougill, A.J.; Stringer, L.C.; Vincent, K.E.; Pardoe, J.; Kalaba, F.K.; Mkwambisi, D.D.; Namaganda, E.; Afionis, S. Climate change adaptation and cross-sectoral policy coherence in southern Africa. Reg. Environ. Chang. 2018, 18, $2059-2071$. [CrossRef]

18. Pilato, G.; Sallu, S.; Gaworek-Michalczenia, M. Assessing the Integration of Climate Change and Development Strategies at Local Levels: Insights from Muheza District, Tanzania. Sustainability 2018, 10, 174. [CrossRef]

19. Tirivangasi, H.M. Regional disaster risk management strategies for food security: Probing Southern African Development Community channels for influencing national policy. Jàmbá J. Disaster Risk Stud. 2018, 10, 1-7. [CrossRef]

20. Lipper, L.; Thornton, P.; Campbell, B.M.; Baedeker, T.; Braimoh, A.; Bwalya, M.; Caron, P.; Cattaneo, A.; Garrity, D.; Henry, K. Climate-smart agriculture for food security. Nat. Clim. Chang. 2014, 4, 1068. [CrossRef]

21. Mathews, J.A.; Kruger, L.; Wentink, G.J. Climate-smart agriculture for sustainable agricultural sectors: The case of Mooifontein. Jàmbá J. Disaster Risk Stud. 2018, 10, 1-10. [CrossRef] [PubMed]

22. FAO (Food and Agricultural Organisation of the United Nations). Climate Change and Food Security: Risks and Responses; FAO: Rome, Italy, 2016.

23. FAO (Food and Agricultural Organisation of the United Nations). Climate-Smart Agriculture—Sourcebook; FAO: Rome, Italy, 2013.

24. FAO (Food and Agricultural Organisation of the United Nations). Energy-Smart Food for People and Climate; FAO: Rome, Italy, 2011.

25. Vermeulen, S.J.; Porter, J.R.; Bennetzen, E. Climate-smart food systems: Plenary presentation. In Proceedings of the Climate Smart Agriculture Global Science Conference, Montpellier, France, 16-18 March 2015.

26. AU-NEPAD-iNGO (The African Union Development Agency-New Partner for African Development-International NonGovernment Organisation). Alliance for Scaling; FAO: Lilongwe, Malawi, 2015.

27. Pernechele, V.; Balié, J.; Ghins, L. Agricultural Policy Incentives in sub-Saharan Africa in the Last Decade (2005-2016). Monitoring and Analysing Food and Agricultural Policies (MAFAP) Synthesis Study; FAO: Rome, Italy, 2018; p. 77.

28. Nunan, F. Making Climate Compatible Development Happen; Routledge: London, UK, 2017.

29. Nyasimi, M.; Amwata, D.; Hove, L.; Kinyangi, J.; Wamukoya, G. Evidence of Impact: Climate-Smart Agriculture in Africa; CCAFS Working Paper; CCAFS: Copenhagen, Denmark, 2014.

30. Wambugu, C.; Franzel, S.; Rioux, J. Options for Climate-Smart Agriculture at Kaptumo Site in Kenya; ICRAF Working Paper; ICRAF: Nairobi, Kenya, 2014; Volume 185.

31. Arslan, A.; McCarthy, N.; Lipper, L.; Asfaw, S.; Cattaneo, A.; Kokwe, M. Climate smart agriculture? Assessing the adaptation implications in Zambia. J. Agric. Econ. 2015, 66, 753-780. [CrossRef]

32. Hammond, J.; Fraval, S.; van Etten, J.; Suchini, J.G.; Mercado, L.; Pagella, T.; Frelat, R.; Lannerstad, M.; Douxchamps, S.; Teufel, N.; et al. The Rural Household Multi-Indicator Survey (RHoMIS) for rapid characterisation of households to inform climate smart agriculture interventions: Description and applications in East Africa and Central America. Agric. Syst. 2017, 151, 225-233. [CrossRef] 
33. Duong, M.T.; Simelton, E.; Le, V.H. Participatory Identification of Climate-Smart Agriculture Priorities; CCAFS Working Paper No. 175; CCAFS: Copenhagen, Denmark, 2016.

34. Mugambiwa, S.S.; Tirivangasi, H.M. Climate change: A threat towards achieving 'Sustainable Development Goal number two' (end hunger, achieve food security and improved nutrition and promote sustainable agriculture) in South Africa. JAMBA (Potchefstroom S. Afr.) 2017, 9, 350. [CrossRef] [PubMed]

35. United Nations Development Programme (UNDP). Africa Human Development Report 2012: Toward a Food Secure Future; United Nations Development Programme: New York, NY, USA, 2012.

36. Rosenstock, T.S.; Lamanna, C.; Chesterman, S.; Bell, P.; Arslan, A.; Richards, M.; Rioux, J.; Akinleye, A.; Champalle, C.; Cheng, Z.; et al. The Scientific Basis of Climate-Smart Agriculture: A Systematic Review Protocol; CCAFS Working Paper No. 138; CGIAR Research Program on Climate Change, Agriculture and Food Security (CCAFS): Copenhagen, Denmark, 2016.

37. Chandra, A.; McNamara, K.E.; Dargusch, P. Climate-smart agriculture: Perspectives and framings. Clim. Policy 2017, 18, 526-541. [CrossRef]

38. Miller, F.A.; Alvarado, K. Incorporating documents into qualitative nursing research. J. Nurs. Scholarsh. 2005, 37, 348-353. [CrossRef]

39. UN (United Nations). World Economic Situation and Prospects 2019; The Department of Economic and Social Affairs of the United Nations: New York, NY, USA, 2019.

40. UN (United Nations). Committee for Development Policy—Report on the Twenty-First Session (11-15 March 2019); United Nations Economic and Social Council: New York, NY, USA, 2019.

41. UNCTAD (United Nations Conference on Trade and Development). The Least Developed Countries Report 2017-Transformational Energy Access; UN: Geneva, Switzerland, 2017.

42. Dinesh, D.; Zougmore, R.B.; Vervoort, J.; Totin, E.; Thornton, P.K.; Solomon, D.; Shirsath, P.B.; Pede, V.O.; Lopez Noriega, I.; Läderach, P.; et al. Facilitating change for climate-smart agriculture through science-policy engagement. Sustainability 2018, 10, 2616. [CrossRef]

43. Un.org. Least Developed Country Category: Malawi Profile. Available online: https://www.un.org/development/desa/dpad/ least-developed-country-category-malawi.html (accessed on 5 July 2019).

44. Un.org. Least Developed Country Category: United Republic of Tanzania Profile. Available online: https://www.un.org/ development/desa/dpad/least-developed-country-category-united-republic-of-tanzania.html (accessed on 5 July 2019).

45. Un.org. Least Developed Country Category: Zambia Profile. Available online: https://www.un.org/development/desa/dpad/ least-developed-country-category-zambia.html (accessed on 5 July 2019).

46. Department of Disaster Management Affairs. National Resilience Strategy (2018-2030). Breaking the Cycle of Food Insecurity in The Republic of Malawi; The Republic of Malawi: Lilongwe, Malawi, 2016.

47. Government of Malawi. THE MALAWI GROWTH AND DEVELOPMENT STRATEGY (MGDS) III—Building a Productive, Competitive and Resilient Nation; The Republic of Malawi: Lilongwe, Malawi, 2017.

48. Ministry of Agriculture, Irrigation and Water Development. National Agriculture Policy; The Republic of Malawi: Lilongwe, Malawi, 2016.

49. Ministry of Agriculture, Irrigation and Water Development and Department of Irrigation. Malawi National Irrigation Strategy; The Republic of Malawi: Lilongwe, Malawi, 2017.

50. Department of Fisheries. National Fisheries Policy 2012-2017; The Republic of Malawi: Lilongwe, Malawi, 2012.

51. Ministry of Agriculture and Food Security. Malawi Agricultural Sector Wide Approach-A Prioritised and Harmonised Agricultural Development Agenda: 2011-2015; The Republic of Malawi: Lilongwe, Malawi, 2011.

52. Michael, S.; Mbwambo, N.; Mruttu, H.; Dotto, M.; Ndomba, C.; da Silva, M.; Makusaro, F.; Nandonde, S.; Crispin, J.; Shapiro, B.; et al. Tanzania Livestock Master Plan; International Livestock Research Institute (ILRI): Nairobi, Kenya, 2018; Available online: http:/ / extwprlegs1.fao.org/docs/pdf/tan185023.pdf (accessed on 15 July 2019).

53. Ministry of Finance and Planning. The Second Five Year Development Plan 2016/17-2020/21; The United Republic of Tanzania: Dodoma, Tanzania, 2016.

54. Ministry of Livestock and Fisheries Development. National Fisheries Policy of 2015; The United Republic of Tanzania: Dodoma, Tanzania, 2015.

55. The United Republic of Tanzania. Agricultural Sector Development Strategy-II 2015/2016-2024/2025; Technical Report; United Republic of Tanzania: Dar es salaam, Tanzania, 2016.

56. The United Republic of Tanzania. Agricultural Sector Development Programme 2 (ASDP II); Prime Minister's Office Regional Administration and Local Government: Dodoma, Tanzania, 2016.

57. Ministry of Agriculture, Food Security and Cooperatives. Agriculture Climate Resilience Plan 2014-2019; United Republic of Tanzania: Dodoma, Tanzania, 2014.

58. Ministry of National Development Planning. SEVENTH NATIONAL DEVELOPMENT PLAN 2017-2021; The Republic of Zambia: Lusaka, Zambia, 2017.

59. Ministry of National Development Planning and Ministry of lands, Natural Resources and Environmental Protection. National Policy on Climate Change; The Republic of Zambia: Lusaka, Zambia, 2016.

60. Ministry of Agriculture and Ministry of Fisheries and Livestock. Second National Agricultural Policy; The Republic of Zambia: Lusaka, Zambia, 2016. 
61. Ministry of Lands, Natural Resources and Environmental Protection. Zambia's National Biodiversity Strategy and Action Plan (NBSAP-2); The Republic of Zambia: Lusaka, Zambia, 2015.

62. Ministry of Agriculture and Livestock. Zambia National Agriculture Investment Plan (NAIP) 2014-2018 Under the Comprehensive Africa Agriculture Development Programme (CAADP); The Republic of Zambia: Lusaka, Zambia, 2013.

63. Nachmany, M. Policy Brief Climate Change Governance in Tanzania: Challenges and Opportunities; Grantham Research Institute on Climate Change and the Environment: London, UK, 2018.

64. Whitfield, S. Adapting to Climate Uncertainty in African Agriculture. Narratives and Knowledge Politics; Routledge: Abingdon, UK, 2015.

65. The World Bank and The Government of Zambia. CLIMATE-SMART AGRICULTURE INVESTMENT PLAN ZAMBIA-Analyses to Support the Climate-Smart Development of Zambia's Agriculture Sector; The World Bank: Washington, DC, USA, 2019.

66. Mugabe, P.A. Assessment of Information on Successful Climate-Smart Agricultural Practices/Innovations in Tanzani. In Handbook of Climate Change Resilience; Leal Filho, W., Ed.; Springer: Berlin/Heidelberg, Germany, 2019.

67. Rockström, J.; Falkenmark, M.; Karlberg, L.; Hoff, H.; Rost, S.; Gerten, D. Future water availability for global food production: The potential of green water for increasing resilience to global change. Water Resour. Res. 2009, 45, 1-16. [CrossRef]

68. Beedy, T.L.; Ajayi, O.C.; Sileshi, G.W.; Kundhlande, G.; Chiundu, G.; Simons, A.J. Scaling up Agroforestry to Achieve Food Security and Environmental Protection among Smallholder Farmers in Malawi. 2013. Available online: https://journals. openedition.org/factsreports/2082 (accessed on 15 July 2019).

69. CIAT (International Centre for Tropical Agriculture). Climate-Smart Agriculture in Zambia. CSA Country Profiles for Africa Series; The World Bank: Washington, DC, USA, 2017.

70. Waha, K.; van Wijk, M.T.; Fritz, S.; See, L.; Thornton, P.K.; Wichern, J.; Herrero, M. Agricultural diversification as an important strategy for achieving food security in Africa. Glob. Chang. Biol. 2018, 24, 3390-3400. [CrossRef]

71. Mango, N.; Makate, C.; Mapemba, L.; Sopo, M. The role of crop diversification in improving household food security in central Malawi. Agric. Food Secur. 2018, 7, 1-10. [CrossRef]

72. Jones, A.D.; Shrinivas, A.; Bezner-Kerr, R. Farm production diversity is associated with greater household dietary diversity in Malawi: Findings from nationally representative data. Food Policy 2014, 46, 1-12. [CrossRef]

73. Rioux, J.; Lava, E.; Karttunen, K. Climate-smart agriculture guideline for the United Republic of Tanzania: A country-driven response to climate change, food and nutrition insecurity. In Food Agriculture Organization Policy Brief; FAO: Rome, Italy, 2017.

74. England, M.I.; Stringer, L.C.; Dougill, A.J.; Afionis, S. How do sectoral policies support climate compatible development? An empirical analysis focusing on Southern Africa. Environ. Sci. Policy 2018, 79, 9-15. [CrossRef]

75. Farnworth, C.R.; Baudron, F.; Andersson, J.A.; Misiko, M.; Badstue, L.; Stirling, C.M. Gender and conservation agriculture in East and Southern Africa: Towards a research agenda. Int. J. Agric. Sustain. 2016, 14, 142-165. [CrossRef]

76. FAO (Food and Agricultural Organisation of the United Nations). The State of Food Security and Nutrition in the World-Building Climate Resilience for Food Security and Nutrition; FAO: Rome, Italy, 2018.

77. Kerr, R.B.; Young, S.L.; Young, C.; Santoso, M.V.; Magalasi, M.; Entz, M.; Lupafya, E.; Dakishoni, L.; Morrone, V.; Wolfe, D.; et al. Farming for change: Developing a participatory curriculum on agroecology, nutrition, climate change and social equity in Malawi and Tanzania. Agric. Hum. Values 2019, 36, 549-566. [CrossRef] 